\title{
ANALISIS KESULITAN MAHASISWA DALAM MENYELESAIKAN SOAL MATRIKS
}

\author{
AMINULLAH \\ Program Studi Teknik Sipil Kampus Mataram UNMAS Denpasar \\ e-mail : aminullahmtk@gmail.com
}

\begin{abstract}
ABSTRAK
Penelitian ini bertujuan untuk mendeskripsikan jenis dan letak kesulitan mahasiswa dalam menyelesaikan soal matriks. Penelitian ini merupakan penelitian survei dengan pendekatan kuantitatif dan kualitatif. Sampel dalam penelitian ini yaitu mahasiswa Program Studi Teknik Sipil Kampus Mataram UNMAS Denpasar sejumlah 13 mahasiswa. Pengambilan data menggunakan instrumen tes dan dianalisis menggunakan analisis kuantitatif-kualitatif. Hasil penelitian ini menunjukkan bahwa jenis kesulitan mahasiswa yang berkaitan dengan fakta sebesar 13,64\%, kesulitan pada konsep sebesar $31,31 \%$, kesulitan pada prinsip sebesar $28,79 \%$ dan kesulitan pada keterampilan sebesar 26,36\%. Sedangkan letak kesulitan mahasiswa pada poin diketahui sebesar $12,52 \%$, poin ditanya sebesar $12,52 \%$, poin rumus sebesar $4,46 \%$, poin sistimatika penyelesaian sebesar $15,78 \%$, poin hubungan antar konsep sebesar $11,15 \%$, poin hubungan fakta-konsep sebesar $12,35 \%$, poin opeasi dasar matematika sebesar $12,41 \%$ dan poin jawaban akhir sebesar $16,81 \%$. Jenis dan letak kesulitan yang paling dominan mahasiswa dalam menyelesaikan soal matriks terdapat pada pemahaman konsep dan jawaban akhir mahasiswa.
\end{abstract}

Kata Kunci: jenis kesulitan, letak kesulitan, soal matriks

\begin{abstract}
This study aims to describe the type and location of student difficulties in solving matrix problems. This research is a survey research with quantitative and qualitative approaches. The sample in this study were 13 students from the Civil Engineering Study Program at Mataram UNMAS Denpasar Campus. Retrieval of data using test instruments and analyzed using quantitative-qualitative analysis. The results of this study indicate that the type of student difficulties related to facts is $13.64 \%$, the difficulty in the concept is $31.31 \%$, the difficulty in principle is $28.79 \%$ and the difficulty in the skill is $26.36 \%$. While the location of students' difficulties on points is known to be $12.52 \%$, points were asked at $12.52 \%$, formula points were $4.46 \%$, systemic completion points were $15.78 \%$, inter-concept links were $11.15 \%$, relationship points facts concepts $12.35 \%$, mathematical basic operating points $12.41 \%$ and final answer points $16.81 \%$. The type and location of the most dominant difficulties students have in solving matrix problems lies in understanding the concepts and final answers of students.
\end{abstract}

Keywords: type of difficulty, difficulty location, matrix problems

\section{PENDAHULUAN}

\section{Latar Belakang}

Matematika merupakan mata pelajaran atau mata kuliah yang sangat luas, bahkan ada di Program Studi Teknik Sipil mata kuliah matematika dipelajari selama tiga semester. Chambers (2008: 9) mengemukakan bahwa "mathematics is a study of pattern, relationship, and rich interconnected ideas (the purist view). It is also a tool for solving problems in a wide range of context (the utilitarian view). Mathematical language is a wonderful way of comunicating ideas, which work across international boundaries, and is not subject to individual interpretations of meaning". Adams \& Hamm (2010: 67) juga menyatakan "mathematics is the science of number and their operations, interrelations, combinations, abstractions, and space 
configurations. The study of abstract structure is central to math. Also, structure, measurement, estimation, generalization, and probability play a role in math-based inquiry".

NCTM (2000: 5) mengemukakan bahwa kompetensi matematika membuka pintu untuk masa depan yang produktif. Jadi, tidak dapat dipungkiri bahwa matematika merupakan mata pelajaran yang sangat penting untuk dipelajari dan berperan dalam pendidikan. Mendikbud (2014: 325) menyebutkan bahwa matematika merupakan ilmu universal yang berguna bagi kehidupan manusia dan juga mendasari perkembangan teknologi modern, serta mempunyai peran penting dalam berbagai disiplin ilmu dan memajukan daya pikir manusia. Salah satu materi dalam mata kuliah Matematika Dasar (Matematika I) yaitu Matriks. Matriks adalah susunan bilangan-bilangan dalam bentuk baris dan kolom yang membentuk suatu persegi/ persegipanjang. Penulisan susunan tersebut dibatasi oleh kurung siku atau kurung biasa.

Mahasiswa dalam belajar matematika khususnya matriks terlihat mengalami kesulitas pada saat menyelesaikan latihan-latihan atau tugas yang diberikan. Hal ini di ketahui dari mahasiswa yang mampu menjawab soal latihan dengan skor diatas 75 kurang dari 60\%. Meskipun mahasiswa tergolong sudah dewasa dan berpengalaman dalam belajar, namun kadang masih mengalami kesulitan atau kendala seperti siswa atau belajar di sekolah pada umumnya. Radatz (Blanco \& Garrote, 2007: 222) menyebutkan bahwa kesulitan siswa dalam menyelesaikan matematika merupakan hasil atau produk dari pengalaman pembelajaran matematika sebelumnya. Kesulitan atau kendala mahasiswa dalam belajar khususnya menyelesaikan soal matriks tidak hanya berasal dari internal mahasiswa itu sendiri tapi juga dipengaruhi oleh banyak faktor seperti kemampuan awal, cara mengajar dosen, lingkungan belajar atau media belajar dan bahkan kepercayaan terhadap matematika itu sendiri. Hal ini sesui menurut Aminullah (2019:251) menyatakan bahwa ada pengaruh kepercayaan siswa pada matematika terhadap kemampuan pemecahan masalah matematis siswa ditunjukkan dengan angka signifikansi pada ANOVA0,038 $\leq 0.05$. Semakin tinggi kepercayaan siswa pada matematika, maka kemampuan pemecahan masalah matematis siswa juga akan semakin meningkat. Aminullah (2020:586) juga menyatakan pengaruh kepercayaan siswa pada matematika terhadap kemampuan berpikir kritis dan hasil belajar siswa memiliki pengaruh yang posistif. Semakin tinggi kepercayaan siswa pada matematika, maka kemampuan berpikir kritis dan hasil belajar siswa juga akan semakin meningkat

Byrnes (2008: 287) mengemukakan bahwa kurang lebih 6\% pada setiap kelas matematika terdapat siswa yang memiliki kesulitan matematika. Kesulitan tersebut meliputi kesulitan prosedural dan kesulitan yang berkaitan dengan fakta matematika. Beberapa contoh kesulitan prosedural yang dialami siswa diantaranya: 1) penggunaan strategi pemecahan masalah yang kurang matang, 2) penggunaan strategi pemecahan masalah yang sama atau monoton dengan lebih lambat, dan 3) sering melakukan kesalahan berhitung. Kesulitan yang berkaitan dengan fakta matematika diantaranya siswa cenderung mengulang dalam memperoleh pengetahuan mengenai fakta matematika dan tidak dapat menyebutkan suatu definisi secara terus menerus. Cooney, Davis \& Henderson (1975: 216-231) mengkategorikan kesulitan ke dalam tiga jenis, yaitu: 1) kesulitan dalam menggunakan konsep, 2) kesulitan dalam menggunakan prinsip, 3) kesulitan dalam memecahkan masalah verbal. Gagne (Bell, 1978: 108) membagi objek-objek matematika yaitu materi yang dipelajari siswa menjadi objek langsung dan objek tidak langsung. Objek langsungnya adalah fakta, keterampilan, konsep, dan prinsip. Sedangkan objek tidak langsungnya adalah kemampuan yang secara tidak langsung akan dipelajari siswa ketika mereka mempelajari objek langsung matematika seperti kemampuan berpikir logis, kemampuan memecahkan masalah, sikap positif terhadap matematika, ketekunan, ketelitian, dan lain-lain. Sehingga dapat dikatakan bahwa kesulitan mahasiswa terletak pada fakta, keterampilan, konsep dan prinsip.

Berdasarkan hasil siswa dalam menyelesaikan soal matriks yang tergolong rendah, maka perlu diadakan analisis atau mencari kendala mahasiswa menggunakan tes diagnostik sehingga dapat dicarikan solusinya. Menurut Nitko \& Brookhart (2011: 130) mendefinisikan bahwa "diagnostic assessment is conducted to identify what knowledge and skills a student has mastered and potential reasons for nonmastery". Sedangkan Abdurrahman (2012: 13) menyatakan bahwa guru lebih dahulu perlu menegakkan diagnosis kesulitan belajar, yaitu menentukan jenis dan penyebab kesulitan serta altenatif strategi pengajaran remidial yang efektif dan efisien. Untuk mendiagnosis kesulitan belajar tersebut perlu dilakukan sebuah tes sehingga guru dapat mengetahui berbagai kesulitan yang dialami siswa. Tes yang digunakan ini disebut sebagai tes diagnostik.

\section{Rumusan Masalah}

Berdasarkan latar belakang, maka rumusan masalah dalam penelitian ini yaitu "(1) Apakah jenis kesulitan mahasiswa dalam menyelesaikan soal matriks ?. (2) Dimanakah letak kesulitan mahasiswa dalam menyelesaikan soal matriks?". 


\section{Tujuan Penelitian}

Tujuan penelitian ini adalah untuk mendeskripsikan jenis dan letak kesulitan mahasiswa dalam menyelesaikan soal matriks.

\section{METODOLOGI PENELITIAN}

Penelitian ini merupakan penelitian survei dengan pendekatan kuantitatif dan kualitatif. Sampel dalam penelitian ini yaitu mahasiswa Program Studi Teknik Sipil Kampus Mataram UNMAS Denpasar sejumlah 13 mahasiswa. Pengambilan data dalam penelitian ini menggunakan instrumen tes dan dianalisis menggunakan analisis kuantitatif-kualitatif. Analisis kuantitatif digunakan untuk menganalisis dan menghasilkan data angka berupa jenis dan letak kesulitan mahasiswa dalam menyelesaikan soal matriks. Sedangkan analisis kualitatif digunakan untuk memperoleh informasi mengenai kesulitan mahasiswa dan digunakan untuk mendeskripsikan jenis, letak dan faktor kesulitan siswa dalam menyelesaikan soal matriks.

Kriteria pengambilan keputusan dalam penelitian ini pada jawaban tes diagnostik sesuai menurut Wasida dan Hartono (2016:82) yang meliputi: (1) jawaban benar, (2) benar tapi kurang lengkap, (3) tidak selesai dijawab, (4) jawaban salah, dan (5) tidak dijawab. Terkait jenis kesulitan dalam menyelesaikan soal meliputi: (1) fakta, (2) konsep, (3) prinsip, dan (4) keterampilan. Sedangkan terkait letak kesulitan dalam menyelesaikan soal meliputi: (1) diketahui, (2) ditanya, (3) rumus, (4) sistematika penyelesaian, (5) hubungan antar konsep, (6) hubungan fakta-konsep, (7) operasi dasar matematika, dan (8) jawaban akhir.

\section{HASIL DAN PEMBAHASAN}

Hasil penelitian ini terfokus pada menunjukkan atau mendeskripsikan jenis dan letak kesulitan mahasiswa dalam menyelesaikan soal matriks sebanyak 10 soal. Berdasarkan data yang diperoleh peneliti dari 13 mahasiswa menunjukkan bahwa jenis dan letak kesulitan mahasiswa sesuai pada tabel 2 dan 3.

Tabel 1. Persentase Hasil Jawaban Tes Diagnostik

\begin{tabular}{|l|c|c|}
\hline \multicolumn{1}{|c|}{ Penyelesaian Siswa } & $\begin{array}{c}\text { Jumlah } \\
\text { Jawaban }\end{array}$ & Persentase \\
\hline Jawaban Benar & 32 & 24.62 \\
\hline Benar tapi Kurang Lengkap & 22 & 16.92 \\
\hline Tidak Selesai Dijawab & 25 & 19.23 \\
\hline Jawaban Salah & 37 & 28.46 \\
\hline Tidak Dijawab & 14 & 10.77 \\
\hline \multicolumn{1}{|c|}{ Total } & $\mathbf{1 3 0}$ & $\mathbf{1 0 0}$ \\
\hline
\end{tabular}

Tabel 1 menunjukkan persentase hasil jawaban tes diagnostik kepada 13 mahasiswa dengan 10 soal tes. Berdasarkan hasil tes menunjukkan bahwa jumlah jawaban yang benar sebanyak 32 atau 24,62\%. Jumlah jawaban yang benar tapi kurang lengkap sebanyak 22 atau 16,92\% dan yang tidak selesai dijawab sebanyak 25 atau $19,23 \%$. Sedangkan jumlah jawaban salah sebanyak 37 atau $28,46 \%$ dan yang tidak dijawab sebanyak 14 atau $10,77 \%$. Jadi, persentase jumlah jawaban tes diagnostik terbanyak yaitu jawaban yang salah. Berkaitan dengan jenis kesulitan mahasiswa dalam menyelesaikan soal matriks dijuntujjan pada tabel 2 di bawah.

Tabel 2. Persentase Jenis Kesulitan Mahasiswa

\begin{tabular}{|l|c|c|}
\hline \multicolumn{1}{|c|}{ Jenis Kesulitan } & Jumlah & Persentase \\
\hline Fakta & 27 & 13.64 \\
\hline Konsep & 62 & 31.31 \\
\hline Prinsip & 57 & 28.79 \\
\hline Keterampilan & 52 & 26.26 \\
\hline \multicolumn{1}{|c|}{ Total } & $\mathbf{1 9 8}$ & $\mathbf{1 0 0}$ \\
\hline
\end{tabular}

Berdasarkan tabel 2 di atas dapat dijelaskan bahwa jumlah jenis kesulitan mahasiswa yang berkaitan dengan fakta ditemukan sebanyak 27 atau sebesar 13,64\% dan kesulitan mahasiswa pada konsep sebanyak 62 atau sebesar 31,31\%. Sedangkan kesulitan mahasiswa pada prinsip sebanyak 57 atau sebesar 28,79\% dan kesulitan dalam keterampilan sebanyak 52 atau sebesar 26,36\%. Jadi dapat dikatakan bahwa jenis kesulitan mahasiswa yang paling dominan dalam menyelesaikan soal matriks terdapat pada pengetahuan konsep.

Jenis kesulitan mahasiswa dalam menyelesaikan soal sesuai dengan hasil penelitian Jana (2018:8) yang menyatakan bahwa kesalahan mahasiswa dalam menyelesaikan soal matematika pada pokok bahasan 
vektor dengan rata-rata kesalahan pemahaman konsep sebesar 33\%. Nurhikmayati (2017:74) juga memperoleh hasil bahwa kesulitan mahasiswa dalam menyelesaikan soal pada mata kuliah Matematika Dasar diantaranya kesulitan pada penggunaan konsep dan prinsip matematika. Imelda (2018:49) menyatakan bahwa mahasiswa mengalami kesulitan penggunaan konsep persamaan dan pertidaksamaan kuadrat, penggunaan konsep rumus-rumus trigonometri. Mahasiswa juga kesulitan dalam penggunan prinsip barisan bilangan dan menyelesaikan penyelesaian persamaan trigonometri, kesulitan mengungkapkan informasi dari soal pemecahan masalah dan kesalahan perhitungan. Jadi, kesulitan mahasiswa diantaranya berkaitan dengan pemahaman atau penggunaan konsep. Sedangkan letak kesulitan mahasiswa ditunjukkan pada tabel 3 di bawah ini.

Tabel 3. Persentase Letak Kesulitan Mahasiswa

\begin{tabular}{|c|c|c|}
\hline Letak Kesulitan & Jumlah & Persentase \\
\hline Diketahui & 73 & 12.52 \\
\hline Ditanya & 73 & 12.52 \\
\hline Rumus & 26 & 4.46 \\
\hline Sistematika Penyelesaian & 92 & 15.78 \\
\hline Hubungan antar Konsep & 65 & 11.15 \\
\hline Hubungan Fakta-Konsep & 72 & 12.35 \\
\hline Operasi Dasar Matematika & 84 & 14.41 \\
\hline Jawaban Akhir & 98 & 16.81 \\
\hline Total & 583 & 100 \\
\hline
\end{tabular}

Berdasarkan tabel 3 di atas dapat dijelaskan bahwa jumlah letak kesulitan mahasiswa pada poin diketahui dan poin ditanya sebanyak 73 atau sebesar $12,52 \%$, jumlah letak kesulitan pada pemahaman atau penggunaan rumus sebanyak 26 atau sebesar $4,46 \%$, kesulitan mahasiswa pada sistimatika penyelesaian sebanyak 92 atau sebesar $15,78 \%$, kesulitan mahasiswa pada hubungan antar konsep sebanyak 65 atau sebesar $11,15 \%$, kesulitan pada hubungan fakta-konsep sebanyak 72 atau sebesar 12,35\%, kesulitan pada opeasi dasar matematika sebanyak 84 atau sebesar $12,41 \%$ dan yang paling dominan letak kesulitan mahasiswa dalam menyelesaikan soal matriks terletak pada jawaban akhir sebanyak 98 atau sebesar 16,81\%. Letak kesulitan mahasiswa dalam menyelesaikan soal sesuai dengan hasil penelitian Jana (2018:8) yang menyatakan bahwa kesalahan mahasiswa dalam menyelesaikan soal matematika pada pokok bahasan vector dalam penarikan kesimpulan sebesar 46,2\%. Jadi, jawaban akhir atau penarikan kesimpulan merupakan salah satu letak kesulitan dalam menyelesaikan soal.

\section{SIMPULAN DAN SARAN}

\section{Simpulan}

Kesulitan mahasiswa dalam menyelesaikan soal matriks dilihat dari hasil tes diagnostik yang meliputi fakta, konsep, prinsip dan keterampilan menunjukkan bahwa jenis kesulitan paling dominan ditemukan pada pemahaman atau penerapan konsep dengan persentase sebesar $31,31 \%$ dan persentase jenis kesulitan yang paling sdikit yiatu pengetahuan atau penerapan fakta sebesar 13,64\%. Sedangkan letak kesulitan yang paling dominan terdapat pada jawaban akhir dengan persentase sebesar 16,81\% dan letak kesulitan yang ditemukan paling sedikit yaitu pada pemahaman atau penggunaan rumus dengan persentase sebesar $4,46 \%$.

\section{Saran-saran}

Berdasarkan hasil penelitian ini, maka saran yang dapat disampaiakan sebagai berikut:

1. Meningkatkan pengetahuan mahasiswa terkait pemahaman tentang fakta, prinsip dan keterampilan dan terutama pemahaman konsep khususnya dalam menyelesaikan soal matriks.

2. Jawaban akhir dalam menyelesaikan soal harus diperhatikan karena dominan kesalahan terletak pada jawaban akhir.

3. Harus dilakukan tes diagnostik terutama mengenai jenis dan letak kesulitan dalam menyelesaikan suatu permasalahan supaya dapat direncanakan solusi tepat. 


\section{DAFTAR PUSTAKA}

Abdurahman, M. (2012). Anak berkesulitan belajar: teori, diagnosis, dan remedialnya. Jakarta: Rineka Cipta.

Adams, D., \& Hamm, M. (2010). Demystify math, science, and technology: Creativity, innovation, and problem solving. Plymouth, UK: Rowman \& Littlefield Publisher, Inc.

Aminullah. (2019). Pengaruh Kepercayaan Siswa pada Matematika terhadap Kemampuan Pemecahan Masalah Matematis Siswa. Jurnal Ganec Swara (http://journal.unmasmataram.ac.id/index.php/GARA) Vol. 13, No. 2, ISSN 1978-0125 (Print); ISSN 2615-8116 (Online), September 2019. 251-257.

Aminullah. (2020). Pengaruh Kepercayaan Siswa pada Matematika terhadap Kemampuan Berpikir Kritis Dan Hasil Belajar Siswa. Jurnal Ganec Swara (http://journal.unmasmataram.ac.id/index.php/GARA) Vol. 14, No. 1, ISSN 1978-0125 (Print); ISSN 2615-8116 (Online), Maret 2020. 251-257. 586-590.

Bell, F. H. (1978). Teaching and learning mathematics (in secondary shcool). Lowa: Browm..

Blanco, L. \& Garrote, M. (2007). Difficulties in learning inequalities in student of first year of pre-university eduacation in spain. EJMSTE, 3, 221-229.

Byrnes, J. P. (2008). Cognitive development and learning in instructional contexts. Boston: Pearson Education, Inc..

Chambers. (2008). Teaching mathematics, developing as a reflective secondary teacher. London: Sage Publication, Inc.

Cooney, T. J., Davis, E. V., \& Henderson, K. B. (1975). Dinamics of teaching secondary school mathematics. Boston: Houghton Mifflin.

Imelda. (2018). Analisis Kesulitan Mahasiswa Dalam Menyelesaikan Soal Pemecahan Masalah Pada Mata Kuliah Aljabar dan Trigonometri. Jurnal MES (Journal of Mathematics Education and Science) ISSN: 2579-6550 (online) 2528-4363 (print) Vol. 4, No. 1, Oktober 2018.49-56

Jana, P. (2018). Analisis Kesalahan Mahasiswa Dalam Menyelesaikan Soal Matematika Pada Pokok Bahasan Vektor. Jurnal Mercumatika : Jurnal Penelitian Matematika dan Pendidikan Matematika Vol. 2, No 2, April 2018, pp. 1-7 ISSN: 2548-1819.

Mendikbud. (2014). Peraturan Menteri Pendidikan dan Kebudayaan Republik Indonesia Nomor 59, Tahun 2014, tentang Kurikulum 2013 SMA/MA. Jakarta

NCTM. (2000). Principles and standards for school mathematics. Reston,VA: Authur.

Nitko, A. J. \& Brookhart, S. M. (2011). Educational Assessment of Student. Boston, MA: Pearson Education, Inc.

Nurhikmayati, L. (2017). Analisis Kesulitan Belajar Mahasiswa pada Matakuliah Matematika Dasar. Jurnal THEOREMS (The Original Research of Mathematics). p-ISSN: 2528-102X e-ISSN: 2541-4321 Vol. 2 No. 1, Juli 2017, 74-85.

Wasida, M. R. dan Hartono, H. (2016). Analisis kesulitan menyelesaikan soal model ujian nasional matematika dan self-efficacy siswa SMA. Jurnal Riset Pendidikan Matematika. ISSN 2356-2684 (print), ISSN 2477-1503 (online). 5 (1), 2018, 82-95. 